\title{
Effect of Orange Juice Consumption on Muscle Damage and Leukocytes Count of Tarung Derajat Athletes
}

\author{
Nurhamida Sari Siregar ${ }^{1}$, Bangun Setia Hasibuan ${ }^{2}$ and Rima Mediyana Sari ${ }^{3}$ \\ nurhamida@unimed.ac.id \\ Department of Sport Science, UNIMED,Williem Iskandar Street, North Sumatera, Indonesia ${ }^{1,3}$ \\ Department of Physical Education, Health and Recreation, UNIMED, North Sumatera, Indonesia ${ }^{2}$
}

\begin{abstract}
The study was conducted to determine the effect of orange juice on muscle damage and leucocytes count of Tarung Derajat Athletes. Subjects were 10 athletes of Tarung Derajat, divided two group: orange juice (OJ) and placebo (PLA), quasi experiment study. Participant were randomized to consume $300 \mathrm{ml}$ OJ or $300 \mathrm{ml}$ PLA and exercise of Tarung Derajat for $12 \mathrm{~d}$. Blood sample were obtained at baseline and 48 post-intervention. Measurement of muscle damage (creatine kinase/CK) and leucocytes count. OJ consumption was no effect on CK level $(\mathrm{p}=0,296>0,05)$ and significantly correlated on leucocytes count $(\mathrm{p}=0,005<0,05)$. OJ have effect on exercise-induced decreases leucocytes count, but no effect on muscle damage.
\end{abstract}

Keywords: Tarung Derajat Athletes, Orange Juice, Muscle Damage, Leucocytes Count

\section{Introduction}

Exercise has caused muscle damage, therefore increased production of reactive oxygen species (ROS) moreover other inflammatory molecules (Aoi et al, 2004). Exercise induced muscle damage followed by reaction an auto-oxidation of hemoglobin and myoglobin, which both has an effect on production and reactivity of ROS (Cooper et al, 2002).

Maximal physical activity caused injuries that triggers inflammation, furthermore stimulates of phagocytes white blood cells to suspended inflammation (Leeuwenburgh and Heinecke, 2001). Normal physical activity, antioxidant eliminating destructive molecules. However, oxidative stress causes an imbalance between free radical production and antioxidant defense. This oxidative stress is involved in aging process, cell damage, muscle damage, muscle fatigue and overtraining (associated with an inadequate recovery) (Finaud, 2006).

High intensity interval training causes an inflammatory response in blood (Belviranli et al., 2017, Fatemah et al., 2014). Furthermore, other studies conducted on trained-untrained subjects, exercise has increasing count of leukocytes in both subjects (Musa et al., 2016).

Leukocytes are white blood cells that function as the body's defenses, containing the nucleus (Ganong, 2010). Therefore, peripheral leukocyte count can be a source of information for diagnosis and prognosis as well as a description of organ damage and recovery after maximal physical activity (Sodique, 2000).

Some research indicated, exercise increased free radical production, caused to increase aerobic energy production. Impact of free radicals could be inhibited by antioxidants. 
Antioxidants could be delay and inhibit oxidation reactions of free radicals, therefore muscle damage, biomolecules damage, such as DNA, proteins, and lipoproteins decreased. Furthermore, the incidence of degenerative disease could be reducing (Devasagayam, et al., 2004).

Some antioxidants were protected cells from free radicals such as vitamins $\mathrm{C}$ and $\mathrm{E}$, carotenoids and flavonoids (Janero, 1991, Packer, 1991), but most commonly used for exercise were vitamin $\mathrm{C}$ and $\mathrm{E}$. One of the fruits that contain vitamin $\mathrm{C}$ is orange, which can be consumed in the form of juice. Nutrient content of orange juice per 228 grams of energy $110 \mathrm{cal}$, carbohydrate $28 \mathrm{~g}$, protein $2 \mathrm{~g}$, calcium $19 \mathrm{mg}$, phosphorus $16 \mathrm{mg}$, vitamin A $15 \mathrm{mcg}$, vitamin C $104 \mathrm{mg}$, vitamin D $2.5 \mathrm{mcg}$, thiamin $2 \mathrm{mg}$, riboflavin $1 \mathrm{mg}$, niacin $8 \mathrm{mg}$, vitain B6 $15 \mathrm{mg}$, folate $61 \mathrm{mcg}$ (Florida Orange Juice, 2018). For this reason, this study was conducted to determine the effect of orange juice on muscle damage and leucocytes count of Tarung Derajat Athletes.

\section{Methods}

\subsection{Subjects and Procedures}

The samples consisted of 10 athletes, consequently, be ready to be the samples, to take part in exercise, did not have a smoke, did not consume vitamin $\mathrm{C}$ supplements during the study.

This research was a quasi-experimental study. Athletes were divided two groups, randomly, OJ and PLA group. Collecting of CK levels and leucocyte counts at the baseline. Thereafter, group 1 was given $300 \mathrm{ml}$ orange juice and exercise Tarung Derajat, group 2 was given placebo $300 \mathrm{ml}$ and exercise Tarung Derajat, for $12 \mathrm{~d}$. Finally, the creatine kinase levels and leukocyte counts were re-collected after $48 \mathrm{~h}$ post-treatment.

Laboratory testing included CK levels and leucocytes count. Laboratory testing were at regional laboratory of North Sumatera. CK testing was by DGKC method and leukocyte testing were by haematology analyzer.

\subsection{Statistical Analyses}

Data analysiswere supported by statistic software "SPSS version 17.0" IBM. Normality test was assessed by Kolmogorov-Smirnov. Mean and standard deviation parameters were calculated. Pair t test were calculated to estimate the effect result on the same group, and independent $t$ test to estimate the effect result on different group. The level of significance was $\mathrm{p}<0.05$. 


\section{Result and Discussion}

We found significant effect of consumption OJ on leucocytes during exercise of Tarung derajat for 12 times, but no significant effect on CK levels

Table 1. Leucocyte counts and CK Level of OJ Group

\begin{tabular}{|c|c|c|c|c|}
\hline \multirow[t]{2}{*}{ Parameters } & \multicolumn{2}{|c|}{ Leucocytes count } & \multicolumn{2}{|l|}{ CK Level } \\
\hline & Before & After & Before & After \\
\hline Mean & 8.478 & 7.020 & 63.80 & 67.20 \\
\hline & $\left(10^{9} / 1\right)$ & $\left(10^{9} / 1\right)$ & $(\mathbf{U} / \mathbf{L})$ & $(\mathbf{U} / \mathbf{L})$ \\
\hline SD & $1.459\left(10^{9} / 1\right)$ & $1.078\left(10^{9} / 1\right)$ & $\begin{array}{l}21.017 \\
\text { (U/L) }\end{array}$ & $\begin{array}{l}8.106 \\
\text { (U/L) }\end{array}$ \\
\hline $\mathrm{p}$ value & \multicolumn{2}{|c|}{0.0} & & 754 \\
\hline
\end{tabular}

*Significant $(\mathrm{p}<0.05)$

There was significant effect of consumption PLA on leucocytes and CK levels during exercise of Tarung Derajat for 12 times.

Table 2. Leucocyte counts and CK Level of PLA Group

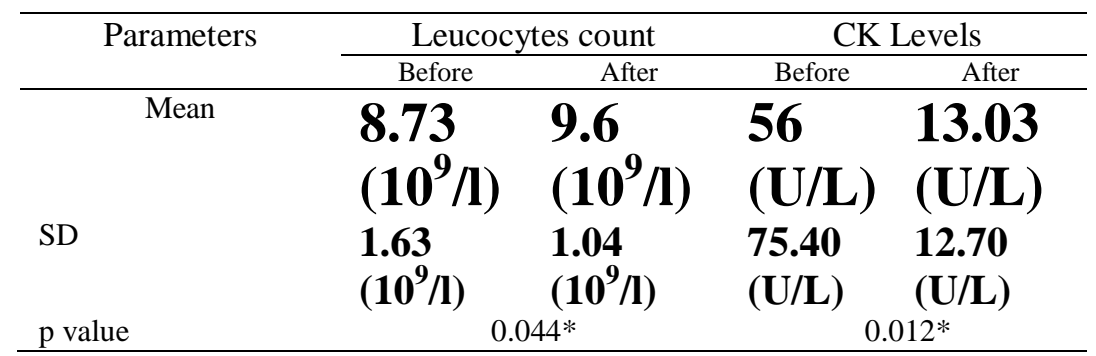

*Significant $(\mathrm{p}<0.05)$

There was an effect of consumption of orange juice on counts of leukocyte athletes. The difference of mean value of leukocyte counts athletes who consumed orange juice and placebo. Athletes who consumed OJ for 12 times during training of Tarung Derajat, evidently, leucocytes count were lower than who consumed PLA. There was no effect of orange juice consumption on creatine kinase levels. There was increased CK level on both groups, the biggest on PLA group. 
Table 3. Leucocyte counts and CK Level of OJ and PLA Group

\begin{tabular}{|c|c|c|}
\hline Parameters & Leucocytes count & CK Levels \\
\hline Mean & $-2.61\left(10^{9} / 1\right)$ & $-8.2(\mathrm{U} / \mathrm{L})$ \\
\hline $\begin{array}{l}\text { SD } \\
\mathrm{p} \text { value }\end{array}$ & $\begin{array}{l}\mathbf{0 . 6 7}(\mathbf{1 0} / \mathbf{l}) \\
0.005^{*}\end{array}$ & $\begin{array}{l}\mathbf{6 . 7 3 8}(\mathrm{U} / \mathrm{L}) \\
0.258\end{array}$ \\
\hline
\end{tabular}

In this research, there was no effect of orange juice consumption on creatine kinase levels, therefore, both of them increased CK level. Orange juice contains vitamin $\mathrm{C}$, which is one source of exogenous antioxidants. As an antioxidant, vitamin $\mathrm{C}$ prevents muscle damage caused by ROS production. ROS arise when oxidizing proteins, fatty acids and DNA in body (Gershoff, S.1993, Harats, et al. 1998).

The enhancement of creatine kinase is an indicator of muscle damage. Exercise-induced metabolic stress causes muscle damage. Metabolic stress occurs due to production of free radicals and excessive amounts of calcium. Increased of activity in electron transport chain, semiquinone in mitochondria and xanthine oxidase in endothelial cell capillaries increases oxygen consumption during exercise (Su Qs, et al., 2010), all of which can lead to increase of production of free radicals and muscle damage.

Consumption of vitamin E supplementation on Deep Sea Marathon athletes, there was no difference in serum creatine kinase levels between two groups (control: $5351.6 \pm 1331.9 \mathrm{U} / \mathrm{L}$ 1 and Vitamin E: $-5337.3 \pm 1058.4 \mathrm{U} / \mathrm{L}-1 ; \mathrm{P}>0.05$ ) although serum creatine levels on vitamin E group were lower. In conclusion, Vitamin E cannot protect increased muscle damage in the Marathon Athlete (Bataineh, et al., 2017).

Increased CK has not been thoroughly explained, but an enhancement CK can be due to an enhancement on muscle temperature. This causes a higher reaction on muscles by increased water loss for thermoregulation. Furthermore, increase of energy oxidation requires higher oxygen loading, which, when combined with a reduction in plasma volume creates a similar situation with a higher intensity of exercise (Cheuvront, 2001, Del Coso et al., 2013), thus causing higher muscle damage than expected.

Some studies suggest that consumption of exogenous antioxidants reduce muscle damage, although in this study orange juice was not significantly proven reduce the impact of exercise on muscle damage. This is supported by the results of other studies showing that there is no effect of supplement consumption on muscle damage. Consumption of lemon verbena extract $(400 \mathrm{mg}$ ) after exercise did not correlate significantly from placebo group on serum creatine kinase in the first 24 hours after exercise $(\mathrm{p}=0.0788)$ (Werner et al., 2018). The combination of vitamin $\mathrm{C}$ and $\mathrm{E}$ supplementation for 6 weeks did not have an impact on reducing muscle damage (Bailey, 2011).

In addition, orange juice also affects the decrease of leukocytes in athletes. Orange juice was a healthy drink that contains vitamins and minerals (Chun, 2007). Orange juice was considered one of the important sources that contain nutrients: vitamin $\mathrm{C}$, folate and potassium. Vitamin $\mathrm{C}$ can protect endothelial cells and LDL from oxidative stress of intraextra cells (Sabharwal, 2008).

Vitamin $\mathrm{C}$ in orange juice can enhance immune system and maintain an effective immune response (Wintergerst, 2007). Several studies has shown that vitamin C strengthens and protects the immune system by stimulating antibody activity and immune system cells such as phagocytes and neutrophils. Some theories state neutralizing ROS production during 
high-intensity exercise by maintaining the redox integrity of immune cells (Wintergerst, 2006).

Vitamin $\mathrm{C}$ is a non-enzymatic antioxidant that dissolves in water. As an antioxidant, vitamin $\mathrm{C}$ works as an electron donor into biochemical reactions both intracellular and extracellular. Intracellular vitamin $\mathrm{C}$ is able to remove reactive oxygen compounds in neutrophil cells, monocytes, lens proteins and retina and react with Fe-ferritin. Outside the cell, vitamin $\mathrm{C}$ is able to remove reactive oxygen compounds, thus preventing oxidation of LDL, transferring electrons intotocopherol oxidized and absorbing metal in the digestive tract (Levine et al., 1995).

Vitamin $\mathrm{C}$ is beneficial for enhancing the immune system and has antioxidant effects. Therefore, vitamin $\mathrm{C}$ also increases immune system through immunological activity of leukocytes, interferon production, inflammatory reactions processes and membrane integrity. Vitamin $\mathrm{C}$ affect on physical performance in athletes due to the synthesis of carnitine in providing energy and enhancing immune function, especially endurance exercise athletes which tends to be more susceptible to upper respiratory infections.

Establishment of free radicals, 5\% of oxygen consumption can be neutralized by endogenous antioxidants. However, if the establish of free radicals increases due to strenuous and tiring exercises, the body's defense system requires exogenous antioxidants to neutralize excess free radicals. If it was not neutralized, an imbalance causes oxidative stress that stimulates leukocyte activity (Cooper, 2000).

In this study, evidently, that consumption of $300 \mathrm{ml}$ orange juice for 12 times during exercise was effective to reduce the count of leukocytes. This is also consistent with other studies which suggest consumption of antioxidant supplements can improve the antioxidant defense system, thereby reducing the impact of oxidative stress induce- exercise (Barr, 2004, Bloomer, 2006).

\section{Conclusions}

This study concluded, creatine kinase levels of orange juice (OJ) group was lower than placebo (PLA) group, whereas it was not significant. Consumption of OJ significantly affected on decrease count of leukocytes. Therefore, in this study, consumption of orange juice reduce the inflammatory response induce-exercise. Our result require confirmation in large study, so the result will be more accurate.

\section{Acknowledgements}

The research was supported by BOPTN of UNIMED.

\section{References}

[1] Aoi, W.: Naito, Y.: Takanami, Y.: Kawai, Y.: Sakuma, K.: Ichikawa, H.: Yoshida, N.: Yoshikawa, T.: Oxidative stress and delayed-onset muscle damage after exercise.Free RadicBiolMed. pp . 480-487.(2004)

[2]Bailey, D.M.: Williams, C.: Betts, J.A.: Thompson, D.: Hurst, T.L.: Oxidative stress, inflammation and recovery of muscle function after damaging exercise. Effect of 6-week mixed antioxidant supplementation. pp. 925-936. (2011) 
[3] Barr,SI.: Rideout, CA.: Nutritional considerations for vegetarian athletes. Nutrition.pp.696-703 (2004).

[4] Bloomer, RJ.: Goldfarb, AH.: McKenzie, MJ.: Oxidative stress response to aerobic exercise: comparison of antioxidant supplements. Med Sci Sports Exerc.pp.1098-1105. (2006)

[5] Bataineh,M.: Al-Nawaiseh, A.: Taifour, A.: Judge, L.: Dead Sea Marathon-Induced Muscle Damage and Acute Oral Vitamine E Supplementation. Journal of Exercise Physiology online. pp.20. (2017)

[6] Belviranli, M.: Okudan, N.: Kabak, B.: The Effects of Acute High-Intensity Interval Training on Hematological Parameters in Sedentary Subjects. Medical Sciences.pp.15(2017)

[7] Bhatti, R.: Shaikh, D.M.: The Effect of Exercise On Blood Parameters. Physiology Journal. 3(2).:pp. 211-215(2007).

[8] Cheuvront, SN.: Haymes EM.: Thermoregulation and marathon running.:Vol. 31(10),pp.743-762 Sports Med (2001)

[9]Chun, OK.: Chung, SJ.: Song, W.O.: Estimated dietary flavonoid intake and major food sources of U.S. adults. J Nutr.:pp.1244-52. (2007)

[10]Cooper, k. H.: Antioxidant revolution. Thomas Nelson Publishers, Tennessee (2000)

[11]Cooper, C.E.: Vollaard, N.B.: Choueiri, T.: Wilson, M.T.: Exercise. Free Radicals and Oxidative Stress. Biochem. 30.pp.280-285 (2002)

[12] DelCoso, J.: Fernández, D.: Abián, Vicen J.: alinero, JJ.: González Millán, C.: Areces, F: Pérez,González B.: Running pace decrease during a marathon is positively related to blood markers of muscle damage. PloS One. pp.57602 (2013)

[13] Finaud, J.: Lac, G.: Filaire, E.: Oxidative stress: relationship with exercise and training. Sports Med.pp.327-358. (2006)

[14]Florida Orange Juice, 2008. Florida Orange Juice Nutrition Facts. https://www.floridacitrus.org/oj/health-nutrition/oj-nutrition-facts. Diakses 30 Agustus 2018.

[15]Ganong, W.F.: Review of medical physiology,Ganong's.Vol.23rd edition. The McGraw-Hill Companies.Inc. USA. (2010)

[16]Gershoff, S.: Vitamin C (ascorbic acid). new roles, new requirements Nutrition Reviews. .pp.313-326. (1993)

[17]Greenwood, M.: Kalman, DS.: Antonio, J.: Nutritional 18. Supplements in sport and exercise. Humana Press. Totowa, USA 2008.

[18]Harats, D.: Chevion, S.: Nahir, M.: Norman, Y.: Sagee, O.: Berry, B.: Citrus fruit supplementation reduces lipoprotein oxidation in young men ingesting a diet high in saturated fat: presumptive evidence for an interaction between vitamins $\mathrm{C}$ and $\mathrm{E}$ in vivo. American Journal of Clinical Nutrition.pp.240-245. (1998)

[19]Hasanloei, F.: Dodman, MK.: Kalantar, J.: Effect of vitamin 19. C intake following exhaustive aerobic exercise on serum immunoglobulins $A$ and $\mathrm{G}$ in karate athletes. International Journal of Sport Studies.pp.327-33. (2013)

[20] I, Musa.: MA, Mabrouk.: Y, Tanko.: The Effect of Exercise and Training Status on Leucocytes Count. International Journal of Current Research in Life Sciences. www.ijcrls.com (2016)

[21]Janero, DR.: Therapeutic potential of vitamin $\mathrm{E}$ in the pathogenesis of spontaneous atherosclerosis.:FreeRadicBiol Med.pp.129-44. (1991)

[22]Leeuwenburgh, C.: Heinecke, J.W.:. Oxidative Stress and Antioxidants in Exercise. Journal of Medicinal Chemistry.pp.829-838.(2001)

[23] Levine, MKR.: Dhariwal, RW.: Welch, Y.: Wang, JB Park.: Determination of optimal vitamin c requirements in humans. The American Journal of Clinical Nutrition.62(Suppl).pp.1347S-1356S.( 1995)

[24]Packer, L.: Protective role of vitamin E in biological systems. Am J ClinNutr.:53.pp.1050S-5S. (1991)

[25]Sabharwal,AK.: May, JM.: Alpha-lipoic acid and ascorbate prevent LDL oxidation and oxidant stress in endothelial cells. Mol Cell Biochem.pp.125-32 (2008)

[26]Sodique, N.O.: Enyikwola.: Ekani,A.U.: Exercise Induced Leucocytosis In Some Healthy Adult Normal. Afr.J. Biomed.Res., 3,.pp. 85-88.(2000) 
[27]Su, QS.: Zhang, JG.: Dong, R.: Hua, B.: Sun, JZ.: Comparison of changes in markers of muscle damage induced by eccentric exercise and ischemia/reperfusion. Scand J Med Sci Sports.pp.748756.(2010)

[28] Werner, S B.: Naka, I.: Wilhelm, M.: Schuzt, E.: Schoen, C.: Reule, C.: Effect of Lemon Verbena Extract (Recoverben) supplementation on muscle strength and recovery after exhaustive exercise: a randomized, placebo-controlled trial. Journal of the International Society of Sport Nutrition.pp.15 (2018)

[29] Wintergerst ,ES.: Maggini, S.: Hornig, DH.: Immune-enhancing role of vitamin C and zinc and effect on clinical conditions. Ann NutrMetab.pp. 50(2): 85-94. (2006)

[30] Wintergerst, ES.: Maggini, S.: Hornig, DH.: Contribution of selected vitamins and trace elements to immune function. Ann NutrMetab .pp.51(4): 301-323. (2007) 